\title{
Czy peer collaboration może stać się obszarem do swobodnego rozwoju naukowego?
}

\author{
dr llona Złoch \\ Uniwersytet Gdański \\ Wydział Oceanografii i Geografii, Zakład Biologii i Ekologii Morza \\ al. Marszatka Piłsudskiego 46, 81-378 Gdynia \\ E-mail: ilona.zloch@ug.edu.pl \\ dr Agata Błaszczyk \\ Uniwersytet Gdański \\ Wydział Oceanografii i Geografii, Zakład Biotechnologii Morskiej \\ al. Marszatka Pitsudskiego 46, 81-378 Gdynia \\ E-mail:agata.blaszczyk@ug.edu.pl
}

Stowa kluczowe: peer collaboration, peer tutoring, rozwój naukowy

Nauczanie rówieśnicze jako naturalny początek uczenia się i nauczania

Wymóg dotyczący poprawy jakości nauczania spowodował, w ostatnich latach, wzrost zainteresowania nauczaniem rówieśniczym w szkolnictwie wyższym. Badania nad nauczaniem i uczeniem się w szkolnictwie wyższym są znacznie mniej obszerne niż badania nad nauczaniem i uczeniem się w szkołach podstawowych i średnich. Chociaż istnieje wiele książek na temat uczenia się dorosłych (np. Richardson Merriam i Caffarella, 1991; Laurillard, 1993, Sutherland 1996), zarówno ilość jak i jakość badań w tej dziedzinie jest zaskakująco ograniczona. Od dawna istnieje obawa, że tradycyjne programy nauczania, realizowane i oceniane $w$ tradycyjny sposób, promują podejście powierzchowne do uczenia się, a nie podejście głębokie lub nawet strategiczne (Entwistle, 1992). Nauczanie $w$ tradycyjnej formie konsekwentnie jest krytykowane za to, że nie promuje rozwoju umiejętności zbywalnych (umiejętności, które można wykorzystać w różnych zawodach) wśród swoich studentów (Barnett, 1992; Ellis, 1993). Jednocześnie zwiększona liczba studentów w połączeniu z ograniczonymi zasobami często skutkuje większymi grupami, zachęcając $w$ ten sposób do powrotu do tradycyjnego stylu prowadzenia wykładów oraz ograniczenia kontaktu w małych grupach - w skrócie, mniej interaktywnego nauczania i uczenia się.

Definicje i typologia nauczania rówieśniczego to bardzo stara praktyka, której korzenie sięgają przynajmniej starożytnych Greków. Archaiczne definicje nauczania rówieśniczego postrzegały nauczyciela równo- 
rzędnego jako nauczyciela zastępczego, w liniowym modelu przekazywania wiedzy, od nauczyciela do nauczyciela. Później uświadomiono sobie, że interakcja nauczania rówieśniczego była jakościowo różna od interakcji między nauczycielem a uczniem i pociągała za sobą różne zalety i wady. Na tym etapie rozwoju mogłaby istnieć definicja: „bardziej zdolni uczniowie pomagają mniej zdolnym uczniom uczyć się we współpracujących parach lub w małych grupach starannie zorganizowanych przez zawodowego nauczyciela". Jednak w miarę postępów badań na temat różnych form nauczania rówieśniczego w ostatnich latach, stało się jasne, że w takim nauczaniu niekoniecznie chodzi tylko o przeniesienie z bardziej zdolnych i doświadczonych (którzy już posiadają wiedzę i umiejętności) do mniej zdolnych (którzy jeszcze ich nie nabyli). W miarę rozwoju tutoringu rówieśniczego jego zdefiniowanie stało się trudniejsze, a obecna definicja wydaje się tak szeroka, że jest raczej nijaka: „ludzie z podobnych grup społecznych, którzy nie są profesjonalnymi nauczycielami, pomagają sobie nawzajem w nauce i uczeniu się poprzez nauczanie". Jednak ta definicja zawiera odniesienie do korzyści wynikających z procesu nauczania dla nauczyciela - w coraz większym stopniu tutoring partnerski ma na celu zwiększenie korzyści zarówno dla nauczanych, jak i nauczycieli. Nauczanie rówieśnicze charakteryzuje się specyficznym przyjmowaniem ról: w dowolnym momencie ktoś pełni rolę nauczyciela, podczas gdy inni pełnią rolę uczniów. Nauczanie rówieśnicze zazwyczaj koncentruje się na treściach programowych. Projekty zwykle określają również dość specyficzne procedury interakcji, w których uczestnicy prawdopodobnie przechodzą szkolenie, które jest specyficzne, ogólne lub jedno i drugie.

Tutoring rówieśniczy jest często promowany na tej podstawie, że dla nauczycieli jest to "uczenie się przez nauczanie". Pogląd ten został rozwinięty w starym powiedzeniu "uczyć to uczyć się dwukrotnie". Teoria inteligentnego działania Sternberga (1985) identyfikuje komponenty, które można ulepszyć podczas tutoringu: umiejętności planowania, monitorowania i oceny oraz związane z tym wykorzystanie wiedzy deklaratywnej, proceduralnej i kontekstowej; oraz procesy poznawcze postrzegania, różnicowania, wybierania, przechowywania, wnioskowania, stosowania, łączenia, uzasadniania i reagowania. Właśnie przygotowanie się do bycia tutorem rówieśniczym zwiększa uwagę i motywację do zadania oraz konieczność przeglądu istniejącej wiedzy i umiejętności. W konsekwencji istniejąca wiedza jest przekształcana przez reorganizację, obejmującą nowe kompozycje i nową integrację. Samo nauczanie pociąga za sobą dalsze wyzwania poznawcze, szczególnie w odniesieniu do uproszczenia, wyjaśnienia i egzemplifikacji.

Podczas wielu rozmów na temat uczenia się rówieśniczego, które odbywają się przy okazji spotkań z innymi nauczycielami akademickimi padło pytanie "Więc co nowego w uczeniu się rówieśniczym można zauważyć?" To pytanie było niewygodne, ponieważ było niewątpliwie właściwe. Dlaczego cała ta otoczka na temat uczenia się rówieśniczego jest tak duża, skoro, ludzie uczą się nawzajem tak długo, jak ludzie pamiętają, ucząc się razem tego, co muszą robić, i najlepszych sposobów, aby to zrobić. Z pewnością nie ma w tym nic nowego. Wydaje się, że nowością, przynajmniej w naszym kraju, jest formalna i relatywnie na dużą skalę instytucjonalizacja tutoringu $\mathrm{w}$ strukturach pedagogicznych szkolnictwa wyższego. Podczas gdy wzajemne uczenie się studentów zawsze było częścią nieformalnej sieci edukacyjnej, formalne wymaganie, aby uczniowie pracowali razem jest stosunkowo nowe. Podobna sytuacja rozwija się w przypadku wykładowców w instytucjach szkolnictwa 
wyższego. Jako nauczyciele akademiccy również mamy długą tradycję wspólnego uczenia się poza salą wykładową - na łamach czasopism naukowych, na konferencjach, a nawet podczas spotkań towarzyskich, gdzie nieuchronnie rozmawiamy o pracy. Członkowie zespołu lub jednostki administracyjnej stają się nieubłaganie zaangażowani we wzajemne nauczanie, czasem nawet w niewygodny sposób. Chociaż nie jest to w żadnym wypadku wszechobecne, zmiana w sposobie współpracy zaczyna być odczuwana w znaczący sposób. Krótko mówiąc, wspólne uczenie się nauczycieli wpływa na kontekst, w którym doświadczamy nauczania, naginając niektóre z naszych podstawowych pojęć pedagogicznych. Nasze założenia dotyczące nauczania i uczenia się tradycyjnie opierają się na autorytecie modelu liniowego. Wyobrażamy sobie, jak stoimy za wiedzą (w naszym otoczeniu), a nasi studenci czekają przede wszystkim przed nami. Myślimy o sobie jako o przekaźnikach i interpretatorach ważnej wiedzy. Uczenie się, które liczy się w kategoriach instytucjonalnych, zdobywanie godzin kredytowych, zmierza w tym samym kierunku, od nas do nich. Oczywiście ta prosta relacja nauczyciel-uczeń nie wskazuje na złożoność relacji między nauczaniem a uczeniem się. Wielu nauczycieli szybko zauważyłoby, że nauczanie to "droga dwukierunkowa" i że uczą się od swoich uczniów. Jednak większość nauczycieli nie jest w stanie wyartykułować, czego uczą się od swoich uczniów. Typowa sytuacja ma często postać serii relacji: uczeń, często słabo przygotowany (cokolwiek to może znaczyć) i mający trudności z zaspokojeniem wymagań nauczyciela, jest wysyłany do korepetytora, gdzie inny nauczyciel pomaga uczniowi w lepszym zaspokojeniu wymagań edukacyjnych stawianych przez nauczyciela. Zatem pojawienie się korepetytorów nie zmienia, przynajmniej na początku, podstawowej koncepcji relacji między tymi ludźmi, gdzie wiedza na jakiś temat przekazywana jest również w ten sam sposób liniowy. W zasadzie to samo można powiedzieć o nauczaniu rówieśniczym: uczeń uczy ucznia, aby zadowolić innego nauczyciela.

Problem, jaki będzie stanowić współpraca rówieśnicza w najbliższych latach, polega po prostu na tym, czy warto ją rozwijać? Czy też nawyki naszej linearnej epistemologii okażą się tak głęboko zakorzenione w naszym życiu instytucjonalnym i zawodowym, że uczenie się $\mathrm{w}$ ramach współpracy $\mathrm{w}$ formie oficjalnego nauczania rówieśniczego będzie postrzegane bardziej jako irytacja niż wkład w edukację. W porównaniu do sytuacji nawet sprzed 10 lat, zamieszkaliśmy w 'szklanych' laboratoriach - nasze prace są coraz bardziej widoczne dla innych naukowców. Nie tylko praca naukowa, ale także wzajemne nauczanie studentów angażuje nauczycieli oficjalnie na różnych poziomach.

\section{Współpraca rówieśnicza jako kolejny etap rozwoju nauczyciela}

Damon i Phelps (1989) wyjaśnili trzy wykluczające się techniki nauczania, które wykorzystują skuteczność interakcji społecznych. Pierwszy, zwany tutoringiem/nauczaniem rówieśniczym, obejmuje doświadczonego rówieśnika, który pomaga mniej doświadczonemu rówieśnikowi. Damon i Phelps twierdzą, że tego rodzaju praca rówieśnicza reprezentuje niski poziom w równości i zróżnicowaniu pod względem wzajemności. Równość odnosi się do względnego poziomu wiedzy zaangażowanych uczniów, a wzajemność odnosi się do wspólnych celów. Druga strategia nauczania wykorzystująca interakcje społeczne nazywa się uczeniem kooperacyjnym i obejmuje indywidualne przypisanie do grup oraz ustrukturyzowane role we współpracy, aby osiągnąć wspólny cel. Tradycyjne strategie uczenia się opartego na współpracy, takie jak Student Teams-Achievement Division (Slavin, 1986) 
i JIGSAW 11 (Aronson, 1978), charakteryzują się wysoką równością, a jednocześnie niską wzajemnością. Poszczególnym uczniom przydzielane są różne zadania, a następnie przenoszone z powrotem do grupy. Trzecia strategia nauczania wykorzystująca interakcje społeczne, współpracę rówieśniczą/peer collaboration, polega na współpracy rówieśników w celu rozwiązania problemów, których nie byliby w stanie rozwiązać samodzielnie. Mówi się, że współpraca rówieśnicza reprezentuje wysoki poziom zarówno pod względem równości, jak i wzajemności. Podczas gdy trzy wymienione powyżej techniki mają pozytywny wpływ na uczenie się, Phelps i Damon (1989) twierdzą, że peer collaboration, w przeciwieństwie do innych technik grupowania, jest przydatną strategią do nauczania pojęć na wysokim poziomie poznawczym. Współpraca rówieśnicza jest podobna do strategii Group Investigation (GI) stosowanych przez Sharana i Sharana (1984) i symuluje wyzwania związane z nauką odkrywania poprzez umieszczenie tych wyzwań w kontekście pomocy i wsparcia. Peer collaboration jako forma współpracy wpisuje się również w teorię rozwoju poznawczego Piageta (1970) obejmującą społeczną genezę wiedzy. Piaget twierdził, że interakcja rówieśnicza może być katalizatorem konfliktu poznawczego, powodując nierównowage i ostatecznie równowagę. Również teoria Sullivana (1953) zapewnia, że rówieśnicy mogą pracować na równi bez wzajemnego kopiowania. Podczas interakcji z rówieśnikami idee są wspólnie formowane, gdy rówieśnicy "dzielą się pomysłami, szukają konsensusu, chętnie idą na kompromis ze sobą i pozostają otwarci na nowe spostrzeżenia".

Kiedy poznaje się nową strategię lub podejście do nauczania, zwykle jest to dość złożony proces, aby skutecznie wdrożyć ją w praktyce. W trakcie tego procesu kluczowe znaczenie ma regularne wsparcie i opinie in- nych ekspertów. Według Sparks (2002), efektywna współpraca rówieśnicza - współpraca nauczycieli z innymi nauczycielami - jest uważana za jeden z najwyższych wskaźników skuteczności w rozwoju nauczycieli. Pozwala uczyć się od kolegów, przekazywać tę wiedzę do praktyki i zastanawiać się nad tym, czego się nauczono.

Płaszczyzny, na których można rozpatrywać peer collaboration obejmują:

- Zdolności - na zasadzie krzyżowania zdolności z tej samej lub innej umiejętności na rzecz wspólnego, głębszego i, miejmy nadzieję, poprawnego zrozumienia

- Ciągłość ról - szczególnie w nauczaniu tej samej umiejętności, role nauczyciela i ucznia nie muszą być stałe. Zorganizowane przełączanie ról w strategicznych momentach (wzajemne nauczanie) może mieć tę zaletę, że wiąże się z większą nowością i większym wzmocnieniem poczucia własnej wartości, ponieważ wszyscy uczestnicy stają się nauczycielami

- Charakterystyka nauczyciela - tradycyjnym założeniem było, że nauczyciele powinni być "najlepszymi uczniami”, tutaj powinni być o podobnym potencjale, aby nie wpaść w pułapkę liniowości w przekazie wiedzy

- Cele - współpraca może dotyczyć osiągnięć intelektualnych, formalnych osiągnięć akademickich, osiągnięć afektywnych i postaw, osiągnięć społecznych i emocjonalnych, osiągnięć w zakresie wizerunku własnego i poczucia własnej wartości lub dowolnej kombinacji.

Peer collaboration w praktyce autorek

Wspólne spotkania w ramach peer collaboration oddzielałyśmy od spotkań prywatnych oraz uczelnianych, tak by pokrywały się z ce- 
lami postawionymi sobie na początku współpracy rówieśniczej. Długość spotkań miała charakter swobodny, to znaczy czasem trwały one pół godziny a czasem nawet 2 godziny. Wszystko zależało od spontanicznego rozwoju sytuacji, którego nie chciałyśmy krępować ograniczeniami czasowymi. Jedynym założeniem pierwotnym, którego przestrzegałyśmy to częstotliwość spotkań, które odbywały się 2 razy w miesiącu.

Dla nas peer collaboration było uczeniem się opartym na natychmiastowej informacji zwrotnej, szybkiej podpowiedzi i większej odpowiedzialności za proces uczenia się w porównaniu z relacją nauczyciel/student. Oprócz natychmiast-owych korzyści poznawczych, otrzymałyśmy nowe zastosowania wiedzy i umiejętności w różnych sytuacjach. Wiele z tego wiąże się z pracą nad własną skutecznością i uczeniem motywowanym, co prowadzi do samoregulacji uczenia się i wydajności. Z psychologicznego punktu widzenia społeczna izolacja nauczycieli akademickich może zostać w ten sposób zmniejszona, przy jednoczesnym zwalczaniu nadmiaru indywidualnej konkurencji między nimi. Jako nauczyciele byłyśmy bardziej zainteresowane swoimi osobowościami, mniej autorytarni we wzajemnej relacji, ale też bardziej skupieni na ocenie. Rosen, Powell i Schubot (1977) dostarczyli dowodów, że zmiana roli z ucznia na nauczyciela jest związana z poprawą osiągnięć. Istnieje również wskazanie, że połączenie z kimś o większej lub równej zdolności wiąże się z większym osiągnięciem. Podsumowując, chociaż istnieją dowody na to, że praca z kimś o porównywalnych zasobach wiedzy zwiększa osiągnięcia, ta forma edukacji jest nadal niewielkim ułamkiem w innych metodach nauczaniach.

Nauczyciele akademiccy, którzy uważają, słusznie lub nie, że ich autorytet jest podważany przez współpracę rówieśniczą lub którzy uważają, że wspólne uczenie się nigdy nie może być czymś więcej niż "niewidomym prowadzącym niewidomych", prawdopodobnie nie poprą pozytywnie formy jaką jest peer collaboration. Dla nas jednymi z największych trudności podczas całego procesu, były: niewielka ilość odniesień w literaturze oraz brak eksperckiego wsparcia. Motywowało nas to do znalezienia "złotego środka", czyli stworzenia takiego obszaru rozwoju naukowego, który dawałby nam swobodę działań bez ograniczeń wymogów akademickich. Wyjęcie spoza ram uczelnianych pracy akademickiej dało nam możliwość zaspokojenia swoich potrzeb rozwojowych, zarówno naukowych jak i intelektualnych. W naszym rozumieniu peer collaboration mogłoby stać się narzędziem wspierającym, które zapobiega wypaleniu zawodowemu. Aby móc się wypalić, trzeba najpierw silnie się zaangażować i tak jest w większości przypadków osób, które zaczynają pracę na uczelniach wyższych. Młodzi pracownicy nieustannie pragną zwiększać poziom własnej wartości, a co za tym idzie dążą do bycia wydajnym i efektywnym pracownikiem. Z czasem to zaangażowanie przekształca się w konieczność, co ostatecznie kończy się wycofaniem z nadmiernie obciążających obowiązków. Towarzyszy temu również m.in. izolacja, inercja w zabraniu się do jakiejkolwiek pracy, utrata zainteresowania oraz obojętność wobec nowych idei. Jednymi z najważniejszych elementów stanowiących swoistą profilaktykę wobec wypalenia zawodowego jest wyznaczanie sobie celów i ich realizacja połączona z własnym rozwojem, włączanie się w działanie jakiejś grupy, umiejętność proszenia o pomoc i ćwiczenie tolerancji. Wiele z powyżej wymienionych elementów odnalazłyśmy w tym sposobie współpracy, choć wiele jeszcze pozostało do wypracowania.

Poza osiągnięciem założonego przez nas celu, ważnym 'zyskiem' dla nas było 
wzbogacenie interakcji rówieśniczych. Zastosowałyśmy narzędzia rozwojowe, które zostały przez nas zmodyfikowane na potrzeby peer collaboration (4 L's, Peer - and Self-Assessment of Collaboration wg Barbary Hall, GOLD). Wynikiem naszej współpracy było udzielanie sobie dodatkowej, regularnej pomocy w rozwiązywaniu problemów, wyraźne porozumienie, tworzenie złożonej struktury argumentów, krytykowanie własnych pomysłów, refleksyjność oraz usprawnienie rozwoju spójnych koncepcji. Wydaję się, że jeśli role w grupie rówieśniczej, gdy nie są przypisane, zmieniają się w zależności od wiedzy każdego członka lub postrzeganej wiedzy specjalistycznej, usprawniając w ten sposób rozwiązywanie problemów i rozwój koncepcji.

\section{Literatura:}

Aronson, E., Stephan, C., Sikes, J., Blaney, N., Snapp, M., 1978. The jigsaw classroom. Sage.

Barnett, R., 1992. Improving Higher Education. Buckingham: Open University.

Damon, W., Phelps, E., 1989. Critical distinctions among three approaches to peer education. International Journal of Educational Research, 13, 9-19.

Ellis, R., 1993. Quality Assurance for University Teaching. Buckingham: Open University Press.

Entwistle, N., 1992. The Impact of Teaching and Learning Outcomes in Higher Education: A Literature Review. Sheffield: Universities and Colleges Staff Development Unit, CVCP

Laurillard, D., 1993. Rethinking University Teaching. Buckingham: Open University Press.

Merriam, R., Caffarella, R.S., 1991. Learning in Adulthood. San Francisco: Jossey-Bass.

Sharan, S., Sharan, Y., 1976. Small Group Teaching, Englewood Cliffs, N.J.: Edcational Technology Publications.
Slavin, R.E., 1986. Using Student Team Learning. 3rd Edition. Baltimore, MD: Johns Hopkins University. Centre for Research on Elementary and Middle Schools. [Google Scholar]

Sparks, D., 2002. Designing powerful staff development for teachers and principals, Oxford, $\mathrm{OH}$ : National Staff Development Council.

Stemberg, R.J., 1985. Beyond I.Q. Cambridge and New York: Cambridge University.

Sullivan, H. S., 1953. The interpersonal theory of psychiatry. New York: Norton.

Rosen, S., Powell, E.R., Schubot, D.B., Rollins, P., 1978. Competence and tutorial role as status variables affecting peer-tutoring outcomes in public school settings. Journal of Educational Psychology, 70(4), 602612.

Notka o autorkach:

dr Ilona Złoch - pracownik naukowo-dydaktyczny Zakładu Biologii i Ekologii Morza na Wydziale Oceanografii i Geografii UG. Jest absolwentką kierunku Oceanografia, Podyplomowego Studium Podstaw Informatyki oraz Studiów Podyplomowych GIS na Uniwersytecie Gdańskim. Jej zainteresowania naukowe skupiają się wokół biocenozy strefy płytkowodnej Zatoki Gdańskiej, w szczególności różnorodności fenotypowej i genotypowej makrofitów oraz roślin naczyniowych. Jako akredytowany praktyk tutoringu, spotyka się z tutee w ramach tematyki szeroko związanej z biologią morza.

dr Agata Błaszczyk - absolwentka Oceanografii oraz Ochrony Środowiska na Uniwersytecie Gdańskim. Obecnie adiunkt w Zakładzie Biotechnologii Morskiej na Wydziale Oceanografii i Geografii UG. Jej zainteresowania naukowe obejmują zagadnienia z zakresu błękitnej biotechnologii. W pracy badawczej skupia się na poszukiwaniu związków biologicznie aktywnych produkowanych 


\section{Tutoring Gedanensis}

przez cyjanobakterie i rośliny morskie, które wykazują interesujący potencjał farmaceutyczny lub kosmetyczny. Ponadto, w kręgu jej pasji naukowych znajduje się tematyka toksycznych zakwitów fitoplanktonu. 